\title{
New data on the jumping spider fauna of Pakistan (Araneae: Salticidae)
}

\section{Новые данные о фауне пауков-скакунчиков Пакистана (Araneae: Salticidae)}

\author{
Muhammad Sajid ${ }^{1}$, John T.D. Caleb ${ }^{*}$, Muhammad Zahid ${ }^{1}$, \\ Shakeel Ahmad ${ }^{3}$ \\ Мухаммад СаджиА ${ }^{1}$, Ажон Е.А. Камеб ${ }^{2 *}$, Мухаммад ЗахиА $^{1}$, \\ Шакия Ахмад ${ }^{3}$
}

\footnotetext{
${ }^{1}$ Department of Zoology Islamia College University, Peshawar, Pakistan.

${ }^{2}$ Zoological Survey of India, Prani Vigyan Bhawan, M-Block, New Alipore, Kolkata 700053, West Bengal, India; email: caleb87woodgate@gmail.com

${ }^{3}$ Department of Animal Sciences, Quaid-E-Azam, University Islamabad, Pakistan.

* Corresponding author.
}

KEY WORDS: Aranei, Dir Lower, distribution, new records, taxonomy.

КЛЮЧЕВЫЕ СЛОВА: Aranei, Нижний Дир, распространение, новые находки, таксономия.

ABSTRACT. Two genera - Portia Karsch, 1878 and Rhene Thorell, 1869 - and six species - Myrmarachne kiboschensis Lessert, 1925, M. prava (Karsch, 1880), Plexippus clemens (O. Pickard-Cambridge, 1872), Portia albimana (Simon, 1900), Rhene flavigera (C.L. Koch, 1846) and Thyene bivittata Xie et Peng, 1995 - are recorded from Pakistan for the first time. A map showing their records in Pakistan is provided.

How to cite this article: Sajid M., Caleb J.T.D., Zahid M., Ahmad Sh. 2020. New data on the jumping spider fauna of Pakistan (Araneae: Salticidae) // Arthropoda Selecta. Vol.29. No.3. P.330-333. doi: 10.15298/arthsel. 29.3.05

PЕЗЮМЕ. Два рода — Portia Karsch, 1878 и Rhene Thorell, 1869 - и шесть видов - Myrmarachne kiboschensis Lessert, 1925, M. prava (Karsch, 1880), Plexippus clemens (O. Pickard-Cambridge, 1872), Portia albimana (Simon, 1900), Rhene flavigera (C.L. Koch, 1846) и Thyene bivittata Xie et Peng, 1995 - впервые отмечаются из Пакистана. Дана карта находок этих видов в Пакистане.

\section{Introduction}

Salticidae is the largest spider family with 647 valid genera and 6166 valid species described worldwide [WSC, 2020]. The knowledge on salticid diversity of Pakistan is poor and a relatively small number of species has been reported [Ali et al., 2018]. A few publications included descriptions of the salticids from Pakistan [Dyal, 1935; Butt, Beg, 2000; Mushtaq et al., $1995 \mathrm{a}, \mathrm{b}]$, but failed to provide adequate descriptions and/or illustrations that would allow a correct identifi- cation. Thus a number of species remain poorly known and, in the absence of the pertinent type material, it is impossible to identify them. For instance, the whereabouts of Dyal's types [1935] is unknown, whereas the types by Butt \& Beg [2000] have been lost. Recent authors [Logunov, 2000; Azarkina, 2004; Logunov et al., 2011; Wesołowska, Freudenschuss, 2012; Ali et al., 2018; Logunov, Ponomarev, 2020] attempted to clarify and provide up to date taxonomic descriptions of the Pakistan salticid fauna.

The present study is aimed at providing records of two genera and six species that are new to Pakistan. Additionally, records of some other salticids from the country is discussed and clarified as well.

Materials and methods

Spiders were hand-collected from different localities of Dir Lower Khyber Pakhtunkhwa (KP), Pakistan. Specimens were preserved in $80 \%$ ethanol and studied under a Labomed (LB-344) stereomicroscope. Identifications were based on diagnostic drawings and keys provided by Wanless [1978a,b], Jastrzębski [2006], Xie \& Peng [1995], Prószyński [1992] and Benjamin [2015]. Nomenclature follows WSC [2020]. Reference lists include only the works that are useful for identification of a corresponding species. The studied specimens are kept in the Museum of the Department of Zoology, Islamia College University (MICU), Peshawar, Pakistan.

\section{Survey of species}

Myrmarachne kiboschensis Lessert, 1925 Map. 


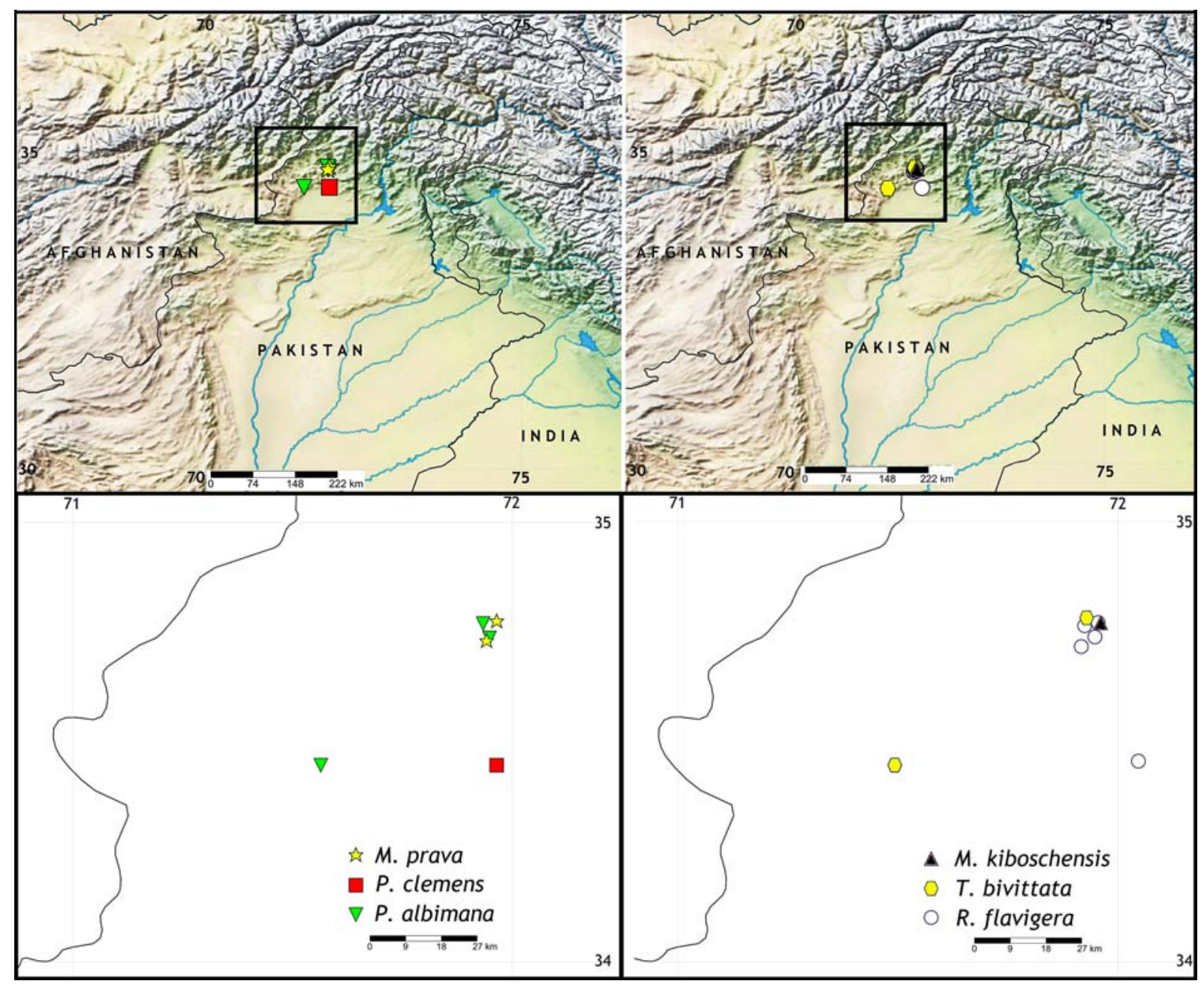

Map. Salticid records from Lower Dir District, Pakistan.

Карта. Точки находок сальтицид в области Нижний Дир, Пакистан.

Myrmarachne kiboschensis: Wanless, 1978a: 78, figs 47A-G,

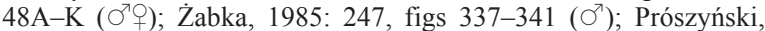
1992: 187, figs 93-98 (O'+

MATERIAL. PAKISTAN: $10^{7}$ (MICU, 878), Dramdal Hills, Talash, Dir Lower, Khyber Pakhtunkhwa $\left(34.77047^{\circ} \mathrm{N}, 71\right.$. $96101^{\circ}$ E), $1368 \mathrm{~m}$ a.s.1., 7.04.2019, M. Sajid.

DISTRIBUTION. The species is known from Botswana (Africa) to Vietnam [WSC, 2020]. It was recently recorded from India [Kananbala et al., 2011] and is reported from northern Pakistan for the first time.

$$
\begin{gathered}
\text { Myrmarachne prava (Karsch, 1880) } \\
\text { Map. }
\end{gathered}
$$

Myrmarachne prava: Benjamin, 2015: 26, figs 23A-E, 24A-D, 25A-D, 27 A-C, 28A-E ( (º); Caleb, 2016b: 414, figs 55-65 ().

MATERIAL. PAKISTAN: 19 (MICU, 667), Galegay Khwar, Talash, Dir Lower, Khyber Pakhtunkhwa $\left(34.77611^{\circ} \mathrm{N}\right.$, $71.96443^{\circ} \mathrm{E}$ ), $1048 \mathrm{~m}, 2.12 .2018$, M. Sajid; 3 우 (MICU, 695697), Toot Shah Hill, Talash, Dir Lower, Khyber Pakhtunkhwa $\left(34.73122^{\circ} \mathrm{N}, 71.94133^{\circ} \mathrm{E}\right), 995 \mathrm{~m}$ a.s.1., 23.12.2018, M. Sajid.

DISTRIBUTION. The species was earlier known from India and Sri Lanka [WSC, 2020] and is first reported from Pakistan; the latter record represents the westernmost limit of the species range.
Plexippus clemens (O. Pickard-Cambridge, 1872) Map.

Plexippus clemens: Logunov, 2010: 87, figs 7-12 (○º); ElHennawy et al., 2015: 131, figs 1-7 ( $\bigcirc^{7}+$ ); Caleb, 2016a: 274, figs $6-10\left(0^{7}\right)$.

MATERIAL. PAKISTAN: $10^{7}$ (MICU, 896), Nagri Payeen, Talash, Dir Lower, Khyber Pakhtunkhwa $\left(34.44751^{\circ} \mathrm{N}\right.$, $\left.71.96430^{\circ} \mathrm{E}\right), 1005 \mathrm{~m}$ a.s.1., 22.04.2019, M. Sajid.

DISTRIBUTION. This species seems to have a wide distribution and is known from Algeria, Israel, Turkey, China, Yemen and India [WSC, 2020]. The present record falls within the known distribution range. Its record from Iran was mentioned to be doubtful [WSC, 2020]; yet it could occur in Iran and adjacent countries from where it has not been recorded yet.

\section{Portia albimana (Simon, 1900) Map.}

Linus albimanus Simon, 1900: 33 (D $\left.{ }^{7}\right)$.

Portia albimana: Wanless, 1978b: 107, figs 12A-D ( $\left.\sigma^{7}\right)$.

MATERIAL. PAKISTAN: $1 \sigma^{\top}$ (MICU, 111), Nagri Payeen, Talash, Dir Lower $\left(34.44752^{\circ} \mathrm{N}, 71.56420^{\circ} \mathrm{E}\right), 1005 \mathrm{~m}$ a.s.1., 11.07 . 
2018, M. Sajid; 2 우 (MICU, 107, 114) Nagri Payeen Zombaqay Hills $\left(34.73711^{\circ} \mathrm{N}, 71.94795^{\circ} \mathrm{E}\right), 1068 \mathrm{~m}$ a.s.1., 1.07.2018, M Sajid; 3 우 (MICU, 875-877) Dramdal Hill, Talash, Dir Lower Khyber Pakhtunkhwa $\left(34.76981^{\circ} \mathrm{N}, 71.93357^{\circ} \mathrm{E}\right), 1292 \mathrm{~m}$ a.s.1, 7.04.2019, M. Sajid.

DISTRIBUTION. The species is distributed from India to Vietnam. Present study confirms its existence in adjacent Pakistan and represents the westernmost record of the species range.

$$
\begin{gathered}
\text { Rhene flavigera (C.L. Koch, 1846) } \\
\text { Map. }
\end{gathered}
$$

Rhanis flavigera C.L. Koch, 1846: 14: 86, figs 1340 (D $\left.\sigma^{7}\right)$. Rhene flavigera: Prószyński, 1984: 119-121 ( $0^{7}, \mathrm{D}+$ ); Żabka, 1985: 443, figs 541-543 (O)

MATERIAL. PAKISTAN: 1 (MICU, 85) Barcharay Hill, Talash, Dir Lower, Khyber Pakhtunkhwa $\left(34.71660^{\circ} \mathrm{N}\right.$, $\left.71.91692^{\circ} \mathrm{E}\right), 1290 \mathrm{~m}$ a.s.1., 18.06.2018, M. Sajid; $2 \sigma^{\top} \sigma^{\top}, 1$ (MICU, 112, 113, 118), Nagri Payeen (Zombaqay Hill), Talash, Dir Lower, Khyber Pakhtunkhwa $\left(34.73844^{\circ} \mathrm{N}, 71.94799^{\circ} \mathrm{E}\right), 968$ $\mathrm{m}$ a.s.1., 1.07.2018, M. Sajid; $3 \bigcirc^{7} \sigma^{\top}, 2$ ơ (MICU, 151-153), Nagri Payeen (Zombaqay and Walay Hills), Talash, Dir Lower, Khyber Pakhtunkhwa $\left(34.73844^{\circ} \mathrm{N}, 71.94799^{\circ} \mathrm{E}\right), 968 \mathrm{~m}$ a.s.1., 3.07.2018, M. Sajid; 1 ( (MICU, MP-180), Banda (Hill), Talash, Dir Lower, Khyber Pakhtunkhwa $\left(34.77111^{\circ} \mathrm{N}, 71.95526^{\circ} \mathrm{E}\right), 1374$ $\mathrm{m}$ a.s.1., 5.07.2018, M. Sajid; 2 우 (MICU, 299, 300), Ajo and Pato Hills, Talash, Dir Lower, Khyber Pakhtunkhwa $\left(34.76397^{\circ} \mathrm{N}\right.$, $71.92471^{\circ} \mathrm{E}$ ), $1242 \mathrm{~m}$ a.s.1., 21.07.2018, M. Sajid; 2 우 (MICU, 64, 65), Nagri Payeen (Godar), Talash, Dir Lower, Khyber Pakhtunkhwa $\left(34.73844^{\circ} \mathrm{N}, 71.94799^{\circ} \mathrm{E}\right) 968 \mathrm{~m}$ a.s.1., 23.08.2018, M. Sajid; 2 O $^{7} \sigma^{7}$ (MICU, 908, 909), Barcharay Hill, Talash, Dir Lower, Khyber Pakhtunkhwa $\left(34.71660^{\circ} \mathrm{N}, 71.91692^{\circ} \mathrm{E}\right), 1290 \mathrm{~m}$ a.s.1., 5.06.2019, M. Sajid; 1 ㅇ (MICU, 961), Khanpur, Adenzai, Dir Lower, Khyber Pakhtunkhwa $\left(34.45613^{\circ} \mathrm{N}, 72.04696^{\circ} \mathrm{E}\right), 757 \mathrm{~m}$ a.s.1., 3.08.2019, M. Sajid.

DISTRIBUTION. The species is known from China to Vietnam and Indonesia (Sumatra) [WSC, 2020]. The record from Pakistan represents the westernmost limit of the species distribution. Both the genus and species are new to Pakistan. The species has not been recorded from India yet, but it is likely to occur there.

\section{Thyene bivittata Xie et Peng, 1995 Map.}

Thyene bivittata Xie et Peng, 1995: 105, figs 1A-E (D $\left.\sigma^{7}\right)$. Thyene bivittata: Jastrzębski, 2006: 1, figs 1-5 $\left(\sigma^{7}\right)$.

MATERIAL. PAKISTAN: $1 \sigma^{7}$ (MICU, 812), Goro, Talash, Dir Lower, Khyber Pakhtunkhwa $\left(34.44711^{\circ} \mathrm{N}, 71.49287^{\circ} \mathrm{E}\right), 766$ m a.s.1., 7.04.2019, M. Sajid; $1 \sigma^{7}$ (MICU, 262), Pato, Talash, Dir Lower, Khyber Pakhtunkhwa $\left(34.78179^{\circ} \mathrm{N}, 71.92913^{\circ} \mathrm{E}\right), 1648 \mathrm{~m}$ a.s.1., 21.07.2018, M. Sajid; $2 \sigma^{\top} \sigma^{\top}$ (MICU, 129), Goro, Talash, Dir Lower, Khyber Pakhtunkhwa $\left(34.44718^{\circ} \mathrm{N}, 71.49282^{\circ} \mathrm{E}\right), 766$ $\mathrm{m}$ a.s.1., 2.09.2018, M. Sajid; $4 \sigma^{\top} \sigma^{7}$ (MICU, 374-377), Goro, Talash, Dir Lower, Khyber Pakhtunkhwa $\left(34.44721^{\circ} \mathrm{N}, 71\right.$. $49285^{\circ}$ E), $768 \mathrm{~m}$ a.s.1., 23.09.2019, M. Sajid.

DISTRIBUTION. T. bivittata was originally described from China [Xie, Peng, 1995] and then recorded from Nepal [Jastrzębski, 2006]. The present record from Pakistan lies at the westernmost limit of the species range.

\section{Discussion}

A total of 37 specimens were examined in the present study resulting in the identification of four genera and six species. All the specimens were collected from different localities in Lower Dir District in Khyber Pakhtunkhwa Province of Pakistan. All the six recorded species - Myrmarachne kiboschensis, Myrmarachne prava, Plexippus clemens, Portia albimana, Rhene flavigera and Thyene bivittata - are new to the salticid fauna of Pakistan. Four of them (M. prava, $P$. albimana, $R$. flavigera and $T$. bivittata) have their westernmost distributional limits of the known ranges.

To date, no reliable information on an overall diversity of the Pakistani Salticidae is available. WSC [2020] lists about 48 species reported from Pakistan, while Metzner [2020] lists 78 species. However, the latter list contains some mistakes and unverified data. For instance, Myrmarachne melanotarsa Wesołowska et Salm, 2002 and Phintella incerta Wesołowska et Russell-Smith, 2000, which were originally described from Kenya and Tanzania respectively, are also included. Likewise, the listed Phintella indica (Simon, 1901), Marpissa tigrina Tikader, 1965, Stenaelurillus lesserti Reimoser, 1934 and Pilia escheri Reimoser, 1934 are known from India only. The occurrence of the following six species is also doubtful requiring confirmation by reference to the pertinent material: Habronattus coecatus (Hentz, 1846), Holcolaetis vellerea Simon, 1910, Langona bristowei Berland et Millot, 1941, Myrmaplata plataleoides (O. Pickard-Cambridge, 1869), M. robusta (Peckham et Peckham, 1892) and Telamonia dimidiata (Simon, 1899). The record of Heliophanus abditus Wesołowska, 1986 could be provisionally accepted, since its data label mentions 'Kurrucke' which seems to refer to Karachi in Pakistan. Metzner's list also includes some species reported by Dyal [1935] e.g., Myrmarachne laeta flava Narayan, 1915, Plexippus rubroclypeatus (Lessert, 1927), Phintelloides versicolor (C.L. Koch, 1846), Plexippus paykulli (Audouin, 1826) — but these records are not included in the Pakistani list by WSC [2020].

With the present new data the list of Pakistani Salticidae reaches up to at least 69 species. More collecting efforts are required to document the entire salticid fauna of Pakistan. Many species currently known from neighbouring countries such as India, China, Afghanistan and Iran are likely to occur in Pakistan as well, and a total number of the Pakistani salticids is expected to rise significantly.

Acknowledgements. We are greatly thankful to Mr Adnan Ahmad, the Head, Department of Geology, University of Swat, KP, Pakistan for allowing us to use the stereomicroscope and camera for digital photography. We are very thankful to the Chairman, DVM Agriculture University, Peshawar for providing facilities for the present study. Our sincere thanks go to Dr. D.V. Logunov (Manchester, UK) for his suggestions, comments and linguistic support which greatly improved the manuscript.

\section{Compliance with ethical standards}

Conflict of Interest: The authors declare that they have no conflict of interest.

Ethical approval: No ethical issues were raised during our research. 


\section{References}

Ali P.A., Maddison W.P., Zahid M., Butt A. 2018. New chrysilline and aelurilline jumping spiders from Pakistan (Araneae, Salticidae) // ZooKeys. Vol.783. P.1-15.

Azarkina G.N. 2004. Two new species of the genus Aelurillus Simon, 1884 from Pakistan and Sri Lanka (Araneae: Salticidae) // Bulletin of the British Arachnological Society. Vol.13. Pt.2. P.49-52.

Benjamin S.P. 2015. Model mimics: antlike jumping spiders of the genus Myrmarachne from Sri Lanka // Journal of Natural History. Vol.49. No.43-44. P.2609-2666.

Butt A., Beg M.A. 2000. Some new species of Marpissa (Salticidae) spiders from Pakistan // Pakistan Journal of Zoology. Vol.32. No.1. P.75-79.

Caleb J.T.D. 2016a. New data on the jumping spiders (Araneae: Salticidae) from India // Arthropoda Selecta. Vol.25. No.3. P.271-277.

Caleb J.T.D. 2016b. Taxonomic notes on some ant-mimicking jumping spiders (Araneae: Salticidae) from India // Arthropoda Selecta. Vol.25. No.4. P.403-420.

Dyal S. 1935. Fauna of Lahore. 4.-Spiders of Lahore // Bulletin of the Department of Zoology of the Panjab University. Vol.1. P.119-252.

El-Hennawy H.K., Mohafez M.A., El-Gendy A.A. 2015. The first record of Plexippus clemens (O.P.-Cambridge, 1872) (Araneae: Salticidae) in Egypt // Serket. Vol.14. No.3. P.128-133.

Ghafoor A., Beg M.A. 2002. Description of two new species of araneid spiders from Pakistan // International Journal of Agricultural Biology. Vol.4. No.4. P.525-527.

Jastrzębski P. 2006. Salticidae from the Himalayas. The genus Thyene Simon 1885 (Arachnida: Araneae) // Acta Arachnologica. Vol.55. P.1-4.

Kananbala A., Bhubaneshwari M., Manoj K., Siliwal M. 2011. A new record of an ant-like salticid spider, Myrmarachne $\mathrm{ki}$ boschensis Lassert [sic], 1925 from Manipur, India // Journal of Experimental Sciences. Vol.2. No.12. P.4-6.

Lessert R. de. 1925. Araignées du Kilimandjaro et du Merou (suite) 5. Salticidae// Revue Suisse de Zoologie. T.31. P.429-528.

Logunov D.V. 2010. Taxonomic notes on a collection of jumping spiders from Iran (Araneae, Salticidae) // Bulletin of the British Arachnological Society. Vol.15. Pt.3. P.85-90.
Logunov D.V., Ballarin F., Marusik Yu.M. 2011. New faunistic records of the jumping and crab spiders of Karakoram, Pakistan (Aranei: Philodromidae, Salticidae and Thomisidae) // Arthropoda Selecta. Vol.20. No.3. P.233-240.

Logunov D.V., Ponomarev A.V. 2020. New species and records of Salticidae (Aranei) from Turkmenistan and neighbouring countries // Arthropoda Selecta. Vol.29. No.1. P.67-81.

Metzner H. 2020. Jumping spiders (Arachnida: Araneae: Salticidae) of the world. Online at https://www.jumping-spiders.com, accessed on 29 April 2020.

Mushtaq S., Beg M.A., Waris M. 1995. A new species and a new record for the genus Phlegra Simon (Araneae: Salticidae) from Pakistan // Pakistan Journal of Zoology. Vol.27. No.3. P.241244.

Mushtaq S., Beg M.A., Waris M., Khan A.A. 1995. Myrmarachne maratha Tikader and Myrmarachne orientales Tikader (Araneae: Salticidae), two new records from Pakistan // Pakistan Journal of Zoology. Vol.27. No.1. P.91-92.

Prószyński J. 1992. Salticidae (Araneae) of India in the collection of the Hungarian National Natural History Museum in Budapest // Annales Zoologici, Warszawa. Vol.44. P.165-277.

Wanless F.R. 1978a. A revision of the spider genera Belippo and Myrmarachne (Araneae: Salticidae) in the Ethiopian region // Bulletin of the British Museum of Natural History (Zool.). Vol.33. No.1. P.1-139.

Wanless F.R. 1978b. A revision of the spider genus Portia (Araneae: Salticidae) // Bulletin of the British Museum of Natural History (Zool.) Vol.34. No.3. P.83-124.

Wesołowska W., Freudenschuss M. 2012. A new species of Menemerus from Pakistan (Araneae: Salticidae) // Arthropoda Selecta. Vol.23. No.3. P.449-453.

WSC 2020. World Spider Catalog. Version 21.0. Natural History Museum Bern, online at http://wsc.nmbe.ch, [accessed on 16th April 2020]. doi: 10.24436/2.

Xie L.P., Peng X.J. 1995. Spiders of the genus Thyene Simon (Araneae: Salticidae) from China // Bulletin of the British Arachnological Society. Vol.10. Pt.3. P.104-108.

Żabka M. 1985. Systematic and zoogeographic study on the family Salticidae (Araneae) from Viet-Nam // Annales Zoologici, Warszawa. Vol.39. P.197-485.

Responsible editor D.V. Logunov 